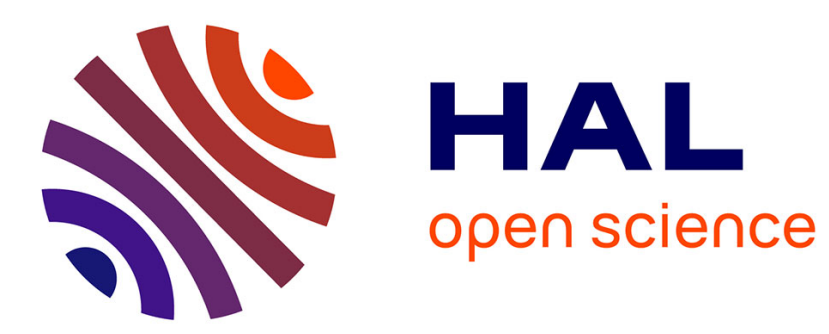

\title{
Managed retreat of settlements and infrastructures: ecological restoration as an opportunity to overcome maladaptive coastal development in France
}

Timothée Fouqueray, Michel Trommetter, Nathalie Frascaria-Lacoste

\section{- To cite this version:}

Timothée Fouqueray, Michel Trommetter, Nathalie Frascaria-Lacoste. Managed retreat of settlements and infrastructures: ecological restoration as an opportunity to overcome maladaptive coastal development in France. Restoration Ecology, 2018, 26 (5), pp.806-812. 10.1111/rec.12836 . hal-02456982

\author{
HAL Id: hal-02456982 \\ https://hal.science/hal-02456982
}

Submitted on 27 Jan 2020

HAL is a multi-disciplinary open access archive for the deposit and dissemination of scientific research documents, whether they are published or not. The documents may come from teaching and research institutions in France or abroad, or from public or private research centers.
L'archive ouverte pluridisciplinaire HAL, est destinée au dépôt et à la diffusion de documents scientifiques de niveau recherche, publiés ou non, émanant des établissements d'enseignement et de recherche français ou étrangers, des laboratoires publics ou privés. 


\section{Title}

2 Managed retreat of settlements and infrastructures: Ecological restoration as an opportunity to

3 overcome maladaptive coastal development in France

4

\section{Running head}

6 Restoration opportunities through managed retreat

7

\section{$8 \quad$ Authors and addresses}

9 Timothée Fouqueray (corresponding author), timothee.fouqueray@agroparistech.fr

10 Écologie, Systématique, Évolution, AgroParisTech, CNRS, Univ. Paris-Sud, Université 11 Paris-Saclay, 91400, Orsay, France

13 Michel Trommetter, mtrommetter@grenoble.inra.fr

14 GAEL, INRA, CNRS, Grenoble INP, Univ. Grenoble Alpes, 38000, Grenoble, France

16 Nathalie Frascaria, nathalie.frascaria@u-psud.fr

17 Écologie, Systématique, Évolution, AgroParisTech, CNRS, Univ. Paris-Sud, Université Paris18 Saclay, 91400, Orsay, France

Author contributions

21 TF conceived, designed, and wrote the paper; MT, NF made additional contributions and 22 edited the manuscript.

24 Abstract 
The effects of climate change on coastal risk factors are increasing due to both rising sea

27 levels and increasingly intense coastal floodings. However, these changes are only just beginning to be incorporated into planning strategies for coastal economies and land use in France. Recent coastal storms marked the turning point, and public authorities have now started to revise coastal management legislation, stating that the managed retreat of settlements and infrastructure is the preferred strategy to adapt to climate change. To date, this managed retreat has almost exclusively been discussed in relation to the current political, social, and economic obstacles that make it difficult to relocate equipment and houses inland. Here, we add to this discussion by depicting how the careful ecological restoration of dunes and salt marshes on land made available by managed retreat could overcome some of these obstacles. First, we describe three possible strategies to adapt to sea-level rise as well as the maladaptation of the current strategy. We then focus on the limitations and advantages of ecological restoration in terms of managed retreat and vice-versa. Finally, we depict how a new kind of land lease, introduced in draft legislation, can help tackle the multitemporal and multispatial issues that currently hinder managed retreat.

\section{Key words}

Adaptation, land use, marine submersion, restoration, sea level, social-ecological

\section{Implications}

- If restorationists do not neglect the social issues that accompany managed retreat, they have a major opportunity to create, restore, and conserve dune ridges, salt marshes, and their associated ecological communities on coastal land made available by managed retreat.

- Drawing from adaptive management, draft legislation introduces "zones of 

management paradigms, and oceans, for which the spatial extent and temporal scales are shown in Table 1.

74

authorization for resilient and temporary activities" that can help serve as an example of adaptation to sea-level rise for coastal land use acts in other countries.

\section{Main text}

\section{INTRODUCTION}

Sea-level rise (SLR) will have major consequences for populations in low-lying coastal areas (Wong et al. 2014). Despite the uncertainties surrounding the expected speed and magnitude of SLR (Carson et al. 2016; Cazenave \& Llovel 2010), it is very likely to exacerbate longterm adverse impacts of storm surges and coastal floodings (Wong et al. 2014). Adaptation policies must therefore be developed to provide strategies for coping with the effects of global warming on coastal areas. Defined as "adjustments in ecological, social, or economic systems in response to observed or expected changes in climatic stimuli and their effects" (Adger et al. 2005), strategic adaptations can be considered to be either reactive (e.g., building dams or dikes after coastal flooding) or proactive. Proactive adaptations are measures taken to lessen the perceived negative impacts of future events (Engle 2011) such as prohibiting housing construction in future coastal flood-prone areas. In France, SLR and its consequences are an extremely important issue because the country's coastlines are of great ecological and economic value (Van Der Maarel 2003; Wong et al. 2014). Indeed, coastlines can be seen as four interconnected subsystems: sediment cells of beaches, coastal municipalities, France was affected by an almost unprecedented winter storm (storm Xynthia) in 2010, which resulted in 47 fatalities and property damage estimated at $€ 1.5$ billion. More winter storms 
three years later exacerbated erosion and damaged man-made structures (Rocle \& Salles

77 2017; Cour des Comptes 2010). Such winter storms diminish atmospheric pressure enough to raise the local sea level and trigger marine submersion (Wong et al. 2014). The fatalities and property damage caused by these storms and consequent flooding led to a national revision of coastal policies to take safety and environmental issues into consideration (Rocle \& Salles 2017). Members of the French Parliament are currently debating updates to coastal land use laws in an attempt to introduce legislative levers that favor adaptations to SLR (Lurton et al. 2017).

In this paper, we focus on a coastal adaptation strategy known as managed retreat (MR), which is encouraged in the new draft of the coastal act. MR is sometimes called "planned retreat" or "managed realignment" and involves an inland relocation of infrastructures currently located on low-lying coastal land (e.g., coastal protection infrastructure, houses, industrial and commercial areas), which is at risk of coastal flooding (Heurtefeux et al. 2011). For example, a seafront road was relocated 40 meters inland between 2007 and 2012 in Sète, a coastal municipality in southern France (Heurtefeux et al. 2011). In France, MR is of particular interest, especially for $25 \%$ of the country's coastlines with observable erosion (around 1,700 km, of which around 1,150 km are low-lying sand coasts) (Mineo-Kleiner 2017), as the retreating coastline draws nearer to infrastructure and jeopardizes it.

We begin here by analyzing the persistent blockages of MR in certain areas. We then present several precautions in order to preserve mutual social and ecological benefits of MR and ecological restoration. Finally, we describe how the renewal of the coastal act presents an opportunity for MR and the ecological restoration of low-lying coastal areas.

We first base our assessment on a review of i) peer-reviewed articles from ecology, economics, geography, and political science journals, mostly published in French since storm Xynthia (2010). We complete these sources with ii) the minutes of meetings on coastal 
101 flooding management involving governmental agencies such as the "Conservatoire du

102 Littoral" (body responsible for preservation of the French coastline) and the "Cour des

103 Comptes" (French supervisor of public subsidies) from the same period, as well as iii)

104 European reports on erosion and coastal adaptation to SLR strategies published since year 105 2000. The review results were supplemented with an exploratory field visit of Port-des106 Barques in March 2017, a municipality affected by storm Xynthia in Charente-Maritime (Fig. $107 \mathrm{~S} 1$ ), as well as personal communication with coastal land use planners.

108

\section{FRENCH COASTLINE PLANNING IS MALADAPTED TO THE EFFECTS OF} EXPECTED CLIMATE CHANGE

Three strategies to adapt to SLR and marine submersions

114 The effects of winter storms are expected to be exacerbated by climate change-related SLR, 115 and although sea-level estimates for 2030 do not exceed $0.07 \mathrm{~m}$, they vary between $0.35 \mathrm{~m}$ and $1161 \mathrm{~m}$ for 2100 (Lurton et al. 2017; Vinchon et al. 2011).

117 Allison and Hobbs (2004) suggest three broad options to adapt to such crises, with different 118 intervention intensities. For municipalities that seek to prevent coastal disturbances, the most 119 interventionist strategy is "command and control," which involves a community actively 120 fighting coastline erosion through the heavy use of technology. This strategy has been used in

121 France in recent decades (Table 1), with the construction of coastal defences such as dikes, 122 groins, seawalls, and geotextile tubes (Touili et al. 2014; Clément et al. 2015). Making 123 "adjustments" through more gentle interventions (e.g., alert systems, insurance systems, 124 flood-proof buildings) is the intermediate strategy (Cour des Comptes 2010). "MR" is the 125 third and least interventionist strategy regarding erosive processes. Relocating sea-front 
126 housing, economic infrastructure (e.g., industrial areas, roads, factories), and strategic

127 buildings (e.g., hospitals, fire stations) means that humans reduce their impact on the coastal

128 ecosystem and adapt to the disturbance instead of repelling it; in this way, MR differs from

129 the default position of doing nothing and corresponds to adaptive management principles

130 (Engle 2011).

131 By relying on the expensive "command and control" strategy, French shorelines are on a 132 maladaptive trajectory, as erosive processes and natural disasters are enhanced by climate 133 change. To date, technological interventions have indeed disrupted beach accretion, and less 134 sediment has been delivered to coasts because of the trapping of riverine sediment behind 135 dams and the diversion of water for irrigation (Wong et al. 2014). Defensive structures 136 dissipate wave energy by causing upwelling and decreasing the amount of sediment deposited 137 at a particular location, thus resulting in down-drift erosion at other locations. Coastal 138 defences therefore need to be constantly extended at a high cost to human lives and society.

140 French coastal municipalities persist in the "command and control" strategy

142 Here, we identify the economic, political, and social obstacles that compel local decision-

143 makers to abide by their current maladaptive strategy of coastal armoring.

144 Economically, insurance companies supported the recovery of coastal inhabitants after storm

145 Xynthia. In France, these companies reimburse policy holders for damage caused by natural 146 disasters using money collected nationally from car and home insurance premiums (Clément 147 et al. 2015). However, the demand for financial compensation is likely to increase 148 unsustainably, because increasing numbers of people (due to the demographic pressure on 149 coastlines) will be exposed to more frequent and intense coastal flooding (Lambert 2015). 150 This economic connectedness of people through their insurance policies is accompanied by 
151 the connectedness of the state and affected municipalities, as the former partially funds the

152 reconstruction of the latter. Coastal recovery was indeed strongly supported by public

153 subsidies following storm Xynthia. For instance, one of the main areas affected by storm

154 Xynthia, the Charente-Maritime department (Fig. S1), launched a $€ 750,000$ television

155 advertising campaign to promote beach tourism, stating that the area would recover and be

156 ready for the summer vacation period. Another $€ 3$ million was spent on restoring sea defences

157 and sand replenishment (Anziani 2010). Such sea defences are contrary to the principles of

158 MR because the authorities could simply wait for the land to become permanently submerged

159 and then claim it as a public maritime domain, a procedure similar to the United States'

160 "rolling easement system" (Siders 2013). Both the tourism-based economy and the financial

161 connectedness between inland and coastal territories participate in maintaining this

162 maladaptive "command and control" management, because the need for taking SLR into

163 account is continually postponed.

164 Socially, the reluctance to change can explain how maladaptive individual and collective

165 behaviors hinder adaptations to SLR. As a coastal community grows and becomes richer, it

166 will apply increasing pressure on local decision-makers to choose sea defences as opposed to

167 MR. For instance, following storm Xynthia, the inhabitants of Charente-Maritime demanded

168 for dikes to be built instead of demolishing vulnerable houses (Mineo-Kleiner \& Meur-Ferec

169 2016). Sea defences support a false sense of security, causing counteradaptive misperceptions

170 of risks (Mineo-Kleiner \& Meur-Ferec 2016). For instance, fatalities could have been avoided

171 if inhabitants trapped in flooded houses had felt vulnerable enough to participate in

172 prevention programs and learn to keep their shutters open, thus allowing for an emergency

173 exit (J. Laugraud, ex-mayor, personal communication). Ultimately, the pressure to build sea

174 defences was applied to mayors, some of whom see coastal land use as an electoral lever

175 through employment and population growth. Local political mandates last for 6 years in 
176 France, which is short relative to the time required for a return on investment in MR.

177 Maladaptive policies therefore fail to reward investment in MR, because benefits are only

178 perceived in the future (Abel et al. 2011).

179 The self-reinforcing first strategy of "command and control" calls for a renewal of recent

180 French coastal policies. So how can MR be an opportunity to implement coastal ecological 181 restoration?

\section{CAN MR BENEFIT ECOLOGICAL RESTORATION AND VICE-VERSA?}

By releasing land, MR can be a chance to create, restore, or preserve coastal ecosystems, as long as care is taken to respect the balance between socio-economic issues and ecological considerations.

Benefits and precautionary measures of MR for ecological restoration

Above all, MR favors ecological restoration by providing habitats for coastal species: the creation, restoration, and conservation of dune ridges and salt marshes benefit coastal plant communities by preventing beaches from steepening and foreshortening (Feagin et al. 2005). MR also improves species resilience to climatic fluctuations by providing habitats for species to recolonize neighboring areas that have become eroded or destroyed (Adger et al. 2005).

196 It is also essential to avoid potentially counterproductive measures of MR in terms of 197 ecological restoration. If the target site has been recently damaged, land released through MR will initially require work to bring it back to the desired environmental trajectory. For soil that has been brought into an artificial state before MR or mechanically disrupted during the 200 demolition of infrastructure during MR, doing nothing favors common species at the expense 
201 of species of ecological interest (Affre et al. 2015). Anthropogenic interventions try to

202

203

204

205

206

207

208

209

210

211

212

213

214

215

216

217

218

219

220

221

222

223

224

225

accelerate ecological recovery at a target site, as illustrated at the Sète lido, where 300,000 marram grass (Ammophila arenaria) seedlings were planted (Vinchon et al. 2011). To improve respect for the site, newsletters and liaison groups were used to explain to visitors why MR is important (Dixon et al. 2008).

On coastlands affected by MR, there may also be species that are protected or of ecological interest. Cases have been reported in which translocation and rescue programs for plants and animals were considered necessary for MR to be successful (Dixon et al. 2008).

Above all, MR involves relocating infrastructure inland, which means that natural or agricultural land away from the coast is at risk of being artificialized. Indeed, the land shortage in France impedes the relocation of houses and equipment to unaffected land (Mineo-Kleiner 2017). There are legal safeguards to avoid displacing urbanization pressure and destroying natural soils such as the prohibition to build on preserved land and injunctions to relocate within urbanized areas. Yet political arbitration between the various sources of local pressure on land makes the task complex, especially since electoral mandates are relatively short (Table 1).

\section{Ecological restoration assets favoring $M R$}

Inversely, ecological restoration presents beneficial side effects for MR. For instance, the revegetation of newly cleared land restores sediment cycling. Dune ridges and salt marshes are ecosystem-based reducers of destructive wave energy, which protect the land (Temmerman et al. 2013). Coupled with wave-breaking plants such as sea grass (Posidonia oceanica) and eelgrass (Zostera marina), ecological restoration as part of MR permits the effective adaptation to coastal erosion and flooding (Temmerman et al. 2013). 
Instead of emphasizing restoration constraints, publicizing the benefits of natural processes

227

228

229

230

231

232

233

234

235

236

237

238 for MR encourages stakeholders with potentially contrasting interests in environmental issues to work together. For example, the restoration of coastal marshes simultaneously increases biodiversity, stores carbon, and limits seawater intrusion (Temmerman et al. 2013; Mossman et al. 2012). Consequently, a relevant integration of the beneficial side effects of MR fosters the transition from a static perspective of biodiversity to a "monitor and adapt" management system (Table 1).

\section{Limitations of MR due to ecological restoration}

Dedicating released land to ecological restoration alone endangers the social acceptability of MR. This can be counteracted by fostering tourism-based employment that relies on the use of light infrastructure (e.g., moveable buildings on stilts) (Mineo-Kleiner \& Meur-Ferec 2016). From this perspective, most MR scenarios include an economic appraisal of the released land by coupling the project with low-impact economic activities. Based on experience, the touristic valuation of restored coastlines is compatible with environmental processes. In terms of cleaning up beaches, it is possible to retrieve non-organic waste alone or leave foreshore tide marks untouched until tourists start frequenting the area. This favors nucleation and the accumulation of sand on dune ridges, because it maintains the supply of organic material to feed dune vegetation and allows sand sequestration (Temmerman et al. 2013; Lambert 2015; Wong et al. 2014). Touristic valuation also sometimes relies on shuttle buses linking beaches to parking lots that no longer stand close to the seaside because of MR.

\section{A DRAFT LAW TO OVERCOME MULTISCALE OBSTACLES TO MR}


MR has been described as a cost-efficient long-term means of coping with the effects of SLR

252 (Abel et al. 2011), and the obstacles for its adoption are well documented. So how can the

253

254

255

256

257

258

draft legislation help French coastal municipalities implement MR?

\section{The rise of MR in research programs}

After storm Xynthia in 2010, the stakeholders who clamored for changes in coastal policies were mostly insurance companies and the Cour des Comptes, or in other words, those paying for the restoration. Public agencies and insurance companies try to refine their decisionmaking by investing in efforts to decrease uncertainty (e.g., SLR celerity, recovery costs after marine submersion). Consequently, scientific projects were launched in France to learn lessons from storm Xynthia (Vinchon et al. 2011). The Sète lido was involved in a call for proposals and partly changed from a "command and control" strategy to MR. This $12 \mathrm{~km}$ long and $2 \mathrm{~km}$ wide strip of sand, which is very popular with tourists, separates the sea from a lagoon on the south coast of France (Fig. S1). The lido also hosts an economic asset: the renowned Listel vineyard, which has been subjected to severe coastal erosion (Heurtefeux et al. 2011). A seafront road was relocated between 2007 and 2012 to allow the sand dunes to recover. The dunes were made more stable using bundles of brushwood, and they now protect the lido (Heurtefeux et al. 2011). MR was partly made possible, because the demand for income from tourism and the support for the well-being of inhabitants, linked to the stability of the beach, were strong, and because no houses had to be relocated (Mineo-Kleiner \& Meur-Ferec 2016). This rare case of MR is distinguished on account of its foresight and longterm investment (MR cost of $€ 54$ million). Interestingly, the French state, which previously granted maladaptive public subsidies for the reconstruction of sea defences, now funds experimental MR. This small change points out to a transformation in the representation of 
human interventions on ecosystems, from a static perception of coastlines to adaptive management practices (Table 1), which are now echoed in the draft legislation.

278

What can a new law do for MR?

The law entitled "Adapting coastal territories to climate change" is currently being passed by the French Parliament (Lurton et al. 2017). Drawing from research outputs such as Sète's results, draft legislation was developed. It is also based on experimental findings from other countries, thanks to exchanges with the UK Environment Agency (Pontee 2007; Creed et al. 2014; Rocle \& Salles 2017). The law will introduce "zones of authorization for resilient and temporary activities," a new type of land lease designed for vulnerable coastal strips. These leases will last between 5 and 99 years, and tenants will be required to leave when the risks exceed a threshold indicated in a prevention plan (Lurton et al. 2017) - hence the legislative interpretation of "resilience" for labile and removable activities (e.g., windsurf schools). Ultimately, the law will also define a "coastline mobility zone" in which natural barriers (e.g., salt marshes and dune ridges) are preferred over manmade sea defences. Governance mechanisms have been designed for a smooth transition to MR, drawing on an economic study of MR cost sharing (see, for example, the insights from a willingness-to-pay analysis in Rey-Valette et al. [2016]).

295 The originality of this draft law is its acknowledgement of the complex social and ecological 296 interdependancies of coastal subsystems with their different spatial and temporal scales 297 (Table 1). With the new type of lease, the draft legislation offers an innovative tool to implement MR as a multiscale "no-regret" solution to SLR. Focusing on the level of coastal municipalities as the main constraint to MR, the decision to end new leases is not motivated by a temporal deadline but instead by a risk threshold that functions as lever against the 
temporal uncertainties of SLR.

302 Moreover, the draft does not set aside the financial crux of MR. The inclusiveness of ecological restoration as a solution to problems of different spatial scales makes it possible to

304 attract various funding, especially when public spending is restricted. Obtaining money from 305 more sustainable sources than public subsidy alone could also help overcome the reluctance 306 of the private sector to become involved. As a land restoration approach, MR has a legitimate 307 place in land use policies when compensating for flood defence and port projects, as 308 investigated (with mixed success) in England (Dixon et al. 2008). Salt marshes formed 309 through MR comply with the criteria from the European Fisheries Fund, because they act as 310 nurseries for fisheries (Dixon et al. 2008). Funding also exists from schemes to protect the 311 connectivity of an area, provided that MR meets the requirement of achieving a good 312 ecological status. The integration of greenhouse gas removal into the European 2030 climate 313 and energy framework is currently underway, setting the stage for possible financial 314 retribution of carbon stocking by MR.

\section{DISCUSSION AND CONCLUSIONS}

318 In our view, the success of MR relies on the inclusion of socio-economic issues in ecological restoration. Coastal municipalities make use of technology (dams, dikes, etc.), anticipate

320 recurring events (marine submersion, storms), and display continual interactions between

321 human and non-human agents on various spatial-temporal scales. Thus, they can be qualified 322 as social-ecological systems, because these processes lead to their establishment, maintenance 323 and reorganization in a form that would otherwise not exist, influencing their capacity to 324 adapt to the effects of SLR (Gunderson \& Holling 2002; Sanderson et al. 2016). From this 325 perspective, and because MR is first intended for human groups and initially depends on 
326 external economic inputs, it can be considered to be a social-ecological restoration

327 (Fernández-Manjarrés et al. 2018). Importantly, this should not be regarded as the intrusion of

328 social issues into ecological restoration, but on the contrary, as an opportunity for ecological

329 restoration to integrate a utilitarian adaptation to climate change.

330 To support the draft law, a relevant holistic narrative could reveal how interlocking economic,

331 political, and social impediments to local change can be addressed using an imperfect, but

332 promising solution: MR. Panarchy, for instance, combines results on various spatio-temporal

333 scales and from various disciplines (economics, ecology, and others) in a single framework.

334 Unlike hierarchical descriptions of top-down systems, panarchy describes the dynamics of

335 nested natural and social systems that interact in creative, destructive, and evolutionary ways.

336 Each system experience growth and a subsequent stabilization, followed by a collapse phase

337 triggered by an external disturbance (in the case of MR, the interacting subsystems could be

338 those decribed in Table 1); the system can then reorganize and start the cycle again

339 (Gunderson \& Holling 2002). Albeit its essentially descriptive approach of social-ecological

340 systems, panarchy is of great help if used in combination with explanatory theories, and has

341 been applied in various research fields including forestry and archeology and other coastal

342 social-ecological systems (Kharrazi et al. 2016; Sanderson et al. 2016).

343 Incentives to switch to MR (i.e., protecting lifes, saving money, restoring ecosystems) are still

344 too weak before the conservative wait-and-see strategy, because of the strong recovery

345 processes and cognitive biases, and because organizations tend to wait for technological

346 developments (Clément et al. 2015; Rey-Valette et al. 2012). Improving the acceptability of

347 MR and ecological restoration as no-regret opportunities is a way to trigger change.

348 Anticipation is the key to transforming the system, and active territorial planning in the

349 French context is a step in this direction (Lurton et al. 2017; Adger et al. 2005; Abel et al.

350 2011). Unlike in the United States, which has market-driven coastal land-planning policies, 
351 the cultural preference in France is for territorial projects with a holistic approach, designed

352 with and by the public authorities. This benefits the implementation of MR (Siders 2013;

353 Mineo-Kleiner \& Meur-Ferec 2016), supported by the positive outcomes of ecological

354 restoration.

355 These particularities of the current context indicate that ecological restoration offers multiple

356 advantages for MR and that the path to adapting the effects of climate change on coastlines is

357 steep but straight.

358

359 Acknowledgments: TF thanks the ENS Lyon for providing a doctoral scholarship, Charente-

360 Maritime inhabitants for valuable discussions, and Guillaume Rieu for logistic support. TF,

361 MT, NF are grateful to two anonymous referees and to the editors for constructive comments.

362 TF, MT, NF thank LabEx BASC for providing a grant (16HGY050). TF, MT, NF have no 363 conflict of interest to declare. 
Abel N, Gorddard R, Harman B, Leitch A, Langridge J, Ryan A, Heyenga S (2011) Sea level rise, coastal development and planned retreat: analytical framework, governance principles and an Australian case study. Environmental Science \& Policy 14:279-288 Adger WN, Hughes TP, Folke C, Carpenter SR, Rockström J (2005) Social-Ecological Resilience to Coastal Disasters. Science 309:1036-1039 Adger WN, Arnell NW, Tompkins EL (2005) Successful adaptation to climate change across scales. Global Environmental Change 15:77-86

Anziani A (2010) Xynthia : les leçons d'une catastrophe (rapport d'étape). Sénat, Paris White N (2016) Coastal sea level changes, observed and projected during the 20th and 21st century. Climatic Change 134:269-281

Cazenave A, Llovel W (2010) Contemporary Sea Level Rise. Annual Review of Marine Science 2:145-173

Clément V, Rey-Valette H, Rulleau B (2015) Perceptions on equity and responsibility in coastal zone policies. Ecological Economics 119:284-291

Cour des Comptes (2010) Les enseignements des inondations de 2010 sur le littoral atlantique (Xynthia) et dans le Var. Cour des Comptes, Paris

Creed S, Maybank M, Pagny J, Comor M, Deniaud G (2014) Living with a Changing Coast LiCCo study site report. European Regional Development Fund, France, United Kingdom Dixon M, Morris RKA, Scott CR, Birchenough A, Colclough S (2008) Managed realignment-lessons from Wallasea, UK. Proceedings of the Institution of Civil Engineers Maritime Engineering 161:61-71

Engle NL (2011) Adaptive capacity and its assessment. Global Environmental Change 21:647-656

Feagin RA, Sherman DJ, Grant WE (2005) Coastal erosion, global sea-level rise, and the loss of sand dune plant habitats. Frontiers in Ecology and the Environment 3:359-364

Fernández-Manjarrés JF, Roturier S, Bilhaut A-G (2018) The emergence of the socialecological restoration concept: Social-ecological restoration concept. Restoration Ecology Gunderson LH, Holling CS, eds. (2002) Panarchy: Understanding Transformations in Human and Natural Systems. Island Press

Heurtefeux H, Sauboua P, Lanzellotti P, Bichot A (2011) Coastal risk management modes: the managed realignment as a risk conception more integrated. In: Risk Management in Environment, Production and Economy. InTech.

Kharrazi A, Fath B, Katzmair H (2016) Advancing Empirical Approaches to the Concept of Resilience: A Critical Examination of Panarchy, Ecological Information, and Statistical Evidence. Sustainability 8:935

Lambert M-L (2015) Le recul stratégique : de l'anticipation nécessaire aux innovations juridiques. VertigO - la revue électronique en sciences de l'environnement

Lurton G, Morel-à-l'Huissier P, Bazin T, Cattin J, Menuel G, Perrut B et al. (2017) Proposition de loi de M. Gilles Lurton portant adaptation des territoires littoraux au changement climatique.

Mineo-Kleiner L (2017) L'option de la relocalisation des activités et des biens face aux risques côtiers: stratégies et enjeux territoriaux en France et au Québec. PhD Thesis, Brest Mineo-Kleiner L, Meur-Ferec C (2016) Relocaliser les enjeux exposés aux risques côtiers en France : points de vue des acteurs institutionnels. VertigO

Mossman HL, Davy AJ, Grant A (2012) Does managed coastal realignment create 
saltmarshes with 'equivalent biological characteristics' to natural reference sites? Elphick, C,

413 editor. Journal of Applied Ecology 49:1446-1456

414 Pontee NI (2007) Realignment in low-lying coastal areas: UK experiences. Proceedings of the 415 Institution of Civil Engineers - Maritime Engineering 160:155-166

416 Rey-Valette H, Rulleau B, Balouin Y, Hérivaux C (2016) Enjeux, valeurs des plages et

417 adaptation des territoires littoraux à la submersion marine. Économie rurale 49-65

418 Rey-Valette H, Rulleau B, Meur-Férec C, Flanquart H, Hellequin A-P, Sourisseau E (2012)

419 Les plages du littoral languedocien face au risque de submersion : définir des politiques de

420 gestion tenant compte de la perception des usagers. Géographie, économie, société 14:369-

421391

422 Rocle N, Salles D (2017) 'Pioneers but not guinea pigs': experimenting with climate change adaptation in French coastal areas. Policy Sciences

424 Sanderson EW, Solecki WD, Waldman JR, Parris A (2016) Prospects for Resilience: Insights from New York City's Jamaica Bay. Island Press

Siders A (2013) Managed Coastal Retreat: A Legal Handbook on Shifting Development Away from Vulnerable Areas. Columbia Law School Public Law \& Legal Theory Working Paper Group, January 10 Temmerman S, Meire P, Bouma TJ, Herman PMJ, Ysebaert T, de Vriend HJ (2013) Ecosystem-based coastal defence in the face of global change. Nature 504:79-83 Touili N, Baztan J, Vanderlinden J-P, Kane IO, Diaz-Simal P, Pietrantoni L (2014) Public perception of engineering-based coastal flooding and erosion risk mitigation options: Lessons from three European coastal settings. Coastal Engineering 87:205-209 Van Der Maarel E (2003) Some remarks on the functions of European coastal ecosystems. Phytocoenologia 33:187-202

Vinchon C, Baron-Yelles N, Berthelier E, Hérivaux C, Lecacheux S, Meur-Férec C, Pedreros R, Rey-Valette H, Rulleau B (2011) MISEEVA : Set up of a transdisciplinary approach to assess vulnerability of the coastal zone to marine inundation at regional and local scale, within a global change context. In: Littoral 2010 - Adapting to Global Change at the Coast: Leadership, Innovation, and Investment. EDP Sciences p. 11003.

441 Wong PP, Losada IJ, Gattuso J-P, Hinkel J, Khattabi A, McInnes KL, Saito Y, Sallenger A 442 (2014) Coastal systems and low-lying areas. In: Climate Change 2014: Impacts, Adaptation, and Vulnerability. Part A: Global and Sectoral Aspects. Contribution of Working Group II to the Fifth Assessment Report of the Intergovernmental Panel on Climate Change. Field, C.B., V.R. Barros, D.J. Dokken, K.J. Mach, M.D. Mastrandrea, T.E. Bilir, M. Chatterjee, K.L. Ebi, Y.O. Estrada, R.C. Genova, B. Girma, E.S. Kissel, A.N. Levy, S. MacCracken, P.R. 
453 Current social-ecological environments of French coastal municipalities with their spatial and

454 temporal scales. Characteristics and scales inspired by Wong et al. (2014), Feagin et al.

455 (2005), Carson et al. (2016), and Mineo-Kleiner (2017).

\begin{tabular}{|c|c|c|c|c|}
\hline & Beach sediment cells & Coastal municipalities & Management practice & Ocean systems \\
\hline $\begin{array}{l}\text { Nature of the } \\
\text { system }\end{array}$ & $\begin{array}{c}\text { Biophysical transport } \\
\text { of sediments }\end{array}$ & $\begin{array}{l}\text { Social and economic } \\
\text { development strategies in } \\
\text { municipalities with } \\
\text { seafront access }\end{array}$ & $\begin{array}{l}\text { Mental representations } \\
\text { of human interventions } \\
\text { regarding ecosystems }\end{array}$ & $\begin{array}{c}\text { Climatic cycles of } \\
\text { oceans }\end{array}$ \\
\hline Spatial scale & $1-10 \mathrm{~km}$ & $5-20 \mathrm{~km}$ & France & Planetary \\
\hline $\begin{array}{l}\text { Temporal extent } \\
\text { under current } \\
\text { functioning }\end{array}$ & Years & $\begin{array}{c}\text { Municipal mandate (6 } \\
\text { years) }\end{array}$ & 10-50 years & $\begin{array}{l}\text { Geological times, } \\
10^{4}-10^{6} \text { years }\end{array}$ \\
\hline $\begin{array}{l}\text { Indicator of } \\
\text { change }\end{array}$ & $\begin{array}{l}\text { Accumulation of } \\
\text { sediments }\end{array}$ & $\begin{array}{l}\text { Population growth and } \\
\text { seasonal affluence of } \\
\text { visitors }\end{array}$ & $\begin{array}{l}\text { Prevalence of } \\
\text { knowledge and } \\
\text { representations of } \\
\text { management practices }\end{array}$ & Sea level \\
\hline $\begin{array}{l}\text { Indicator of } \\
\text { resilience }\end{array}$ & $\begin{array}{l}\text { Seasonal return of } \\
\text { beach vegetation }\end{array}$ & $\begin{array}{l}\text { Return rate of population } \\
\text { and visitors after } \\
\text { disturbance }\end{array}$ & $\begin{array}{l}\text { Ability of the current } \\
\text { values to keep leading } \\
\text { coastal policies }\end{array}$ & $\begin{array}{c}\text { Latence time } \\
\text { needed to return } \\
\text { to pre-industrial } \\
\text { periodic } \\
\text { oscillations of } \\
\text { geological climate }\end{array}$ \\
\hline $\begin{array}{c}\text { Former state of the } \\
\text { system }\end{array}$ & $\begin{array}{c}\text { Balance between } \\
\text { erosion and sediment } \\
\text { accumulation }\end{array}$ & $\begin{array}{c}\text { Plans for tourism } \\
\text { development, population } \\
\text { growth, gradual } \\
\text { institutionalization of } \\
\text { conflict resolution through } \\
\text { property rights or coastal } \\
\text { laws }\end{array}$ & Command and control & $\begin{array}{l}\text { Pre-industrial sea } \\
\text { level }\end{array}$ \\
\hline $\begin{array}{l}\text { Current state of the } \\
\text { system }\end{array}$ & Coastline retreat & $\begin{array}{l}\text { Coastal armoring, tourist } \\
\text { and transportation } \\
\text { saturation, with } \\
\text { degradation of tourist } \\
\text { resorts by winter storms }\end{array}$ & $\begin{array}{l}\text { Static perception of } \\
\text { coastline land use (no } \\
\text { influence of } \\
\text { environmental changes) } \\
\text { with conflicting rules } \\
\text { and consolidated } \\
\text { institutions }\end{array}$ & Sea-level rise \\
\hline $\begin{array}{c}\text { State of the system } \\
\text { under managed } \\
\text { retreat }\end{array}$ & $\begin{array}{l}\text { Dune and salt marsh } \\
\text { revegetation }\end{array}$ & $\begin{array}{l}\text { Managed retreat economy: } \\
\text { beach tourism, outdoor } \\
\text { recreative coastal usage }\end{array}$ & $\begin{array}{l}\text { Adaptive management } \\
\text { of climate change, } \\
\text { "monitor and adapt" } \\
\text { approach }\end{array}$ & $\begin{array}{l}\text { Uncertainties, but } \\
\text { projected higher } \\
\text { sea levels and } \\
\text { disrupted marine } \\
\text { streams }\end{array}$ \\
\hline
\end{tabular}

